\title{
Each person has a science of planting: plants cultivated by quilombola communities of Bocaina, Mato Grosso State, Brazil ${ }^{1}$
}

\author{
Thais Aparecida Coelho dos Santos² and Flávio Bezerra Barros ${ }^{3,4}$
}

Received: 1.06.2016; accepted: 7.03.2017

\begin{abstract}
Each person has a science of planting: plants cultivated by quilombola communities of Bocaina, Mato Grosso State, Brazil). The objective of this study was to record the most important vegetal resources in the life of the quilombolas of Bocaina, emphasizing the practices of agrobiodiversity management. We used semi-strutured and informal interviews, free list, and participant observation. For records, we used a field diary, photos, and recordings. For analysis, we performed calculations of absolute and relative frequencies, linear regression analysis to verify relations between age and species richness, Detrended Correspondence Analysis (DCA), and diversity profile. We recorded a total of 180 species, of which, the most cited plants were food crops cultivated in backyards and clearings. Ninety-seven medicinal species used for various diseases were recorded. The most common form of use is leaf tea. We verified that the plants management is of agroecological character favoring biodiversity maintenance. We concluded that the Community, by means of its traditional knowledge, performs agroecological management of the plants, promoting food security for its family and conservation of genetic resources.
\end{abstract}

Keywords: agrobiodiversity, traditional knowledge, backyards, quilombolas, porto estrela municipality

RESUMO - (Cada pessoa tem uma ciência de plantar: plantas cultivadas pelos quilombolas da Bocaína, MT, Brasil). O objetivo deste estudo foi registrar os recursos vegetais mais importantes na vida dos quilombolas da Bocaina, enfatizando as práticas de manejo da agrobiodiversidade. Utilizamos entrevistas semiestruturadas e informais, lista livre e observação participante. Para o registro, usamos diário de campo, fotografias e gravações, para análise realizamos cálculos de frequências absoluta e relativa, análise de regressão linear para verificar relações entre idade e riqueza de espécies, e análise de Correspondência Destendenciada (DCA). Registramos um total de 180 espécies, das quais, as plantas mais citadas foram as alimentícias, cultivadas em quintais e roças. Foram registradas 97 espécies medicinais, utilizadas para diversas doenças. A forma mais comum de uso é o chá da folha. Constatamos que o manejo das plantas é de caráter agroecológico favorecendo a manutenção da biodiversidade. Concluímos que a comunidade, por meio de seus conhecimentos tradicionais, realiza o manejo agroecológico das plantas, promovendo segurança alimentar para sua família e conservação de recursos genéticos. Palavras-chave: agrobiodiversidade, conhecimento tradicional, quintais, quilombolas, Porto Estrela

\section{Introduction}

The species are target of knowledge, of domestication and use, source of inspiration to myths and rituals of traditional societies and, finally, goods in modern societies, thus, biological diversity cannot be considered simply as a concept of the natural world, but rather as a cultural and social construction (Diegues 2000). In this sense, Emperaire (2004) says that in a context marked by the erosion of agricultural diversity and increased interest in these resources, as molecules reservoirs or genes of economic potential, the conservation of agricultural biodiversity goes beyond the conservation of genetic resources of the plant, it is the conservation of a cultural heritage.

In the Brazilian territory the traditional communities and the small farmers perform the plants management for a long time, so that the plants are used in different ways for different purposes. This management provided the establishment of a broad diversity of species and plant varieties, accompanied by a collection of local knowledge. The fact that these communities have their economy focused on the production of subsistence and sale of surpluses, allowing them to remain in their place of

1. Parte do Trabalho de Dissertação de Mestrado do primeiro Autor

2. Universidade do Estado de Mato Grosso, Mestrado em Ciências Ambientais, Av. Santos Dumont, s/n - Cidade Universitária, Bloco II, 78200-000 Cáceres, MT, Brasil

3. Universidade Federal do Pará, Núcleo de Ciências Agrárias e Desenvolvimento Rural, Rua Augusto Corrêa, nº 1, Campus Guamá, 66075-110 Belém, PA, Brasil

4. Corresponding Author: flaviobb@ufpa.br 
origin, enables that the maintenance of plant diversity be of fundamental importance for the traditional communities, as also to society in general (Pilla \& Amorozo 2009). Thus, these Communities retain a knowledge of how to cultivate a range of species adequate to change a habitat, agricultural practices that can be mobilized to meet the needs of a changing world (Barthel et al. 2013).

The socioeconomic transformations, on the way how to use the land, as well as in the use of other natural assets, have placed at risk also the nature balance. The nature richness, characterized by diversity is destroyed to create commercial wealth characterized by uniformity, with this, the natural diversity of the forest is seen as "grass-weed", and therefore needs to be destroyed (Shiva 2003). The recognition that there was erosion in ecological heterogeneity in multiple spatial and temporal scales, as a result of intensive agriculture, can help to unify the response of conservation of agricultural practices which are directed to the increased heterogeneity, instead of its discard (Benton et al. 2003).

In this context it is included the Cerrado Biome, which has been suffering negative consequences, biologically and socially, due to the advancement of modernization, since they are in those regions where the large agricultural enterprises are found. Cerrado, which is formed by a diverse landscape, open vegetation and environment characterized by light, is the holder of a significant portion of the planet's biodiversity and has a priceless cultural heritage (Pacari 2006).

Agriculture is a human way of using natural, physical and biological assets, for feeding, healing, building shelter, producing fibers and generating income, with this there is the agribiodiversity, where the human factor - the farmers - play a decisive role in the development of diversity in agriculture (Boef 2007). The agrobiodiversity can be understood as a process of relations of diversity management among species and among them, with the traditional knowledge and with the management of multiple agroecosystems, as being the cutout of biodiversity (Machado 2007). A millennial methodology is the conservation by use, in which farmers all over the world cultivate, retain, produce food, fibers and other needs in a sustainable way (Nodari \& Guerra 2015). Thus, the local knowledge systems have proved in many cases, a description of local environments, superior in detail and coherence with the biological sciences, such descriptions are based on a life of intimate daily observation, a luxury that is not available to biologists (Hunn 1999).

Finally, interpreting the management systems and the relations that link the small producers with vegetable or animal species, allow to understand the existing biodiversity in their environment. Given the fact that every time we are losing our biodiversity, knowledge of traditional populations and also the plants they cultivate become relevant to provide the scientific community with information about the nature operation, as well as endangered native species. The objective of this study was to record the most important vegetable resources in the Bocaina's quilombolas life, emphasizing the practices of agrobiodiversity management.

\section{Materials and methods}

Study Area - In the 1970s the Bocaina community's inhabitants, located in Porto Estrela municipality, Mato Grosso State, were expelled from their locality of origin, due to the livestock advance that occurred at that time in this town. The expulsions occurred in several ways for families, ranging from coercions, land overlap, and even false deeds, lastly, in function of the various pressures the families were pressed to leave the territory, territory which had been occupied for many generations and which provided the basis for their livelihood. The process of deterritorialization made the families to separate and, today they live "scattered all over", a local term to say that they are distributed in several places, thus, the people are established at various locations and municipalities of the State of Mato Grosso. However, some families settled down in the vicinity of the Serra da Bocaina, in surroundings of Ecological Station Serra das Araras, where the communities Pé de Galinha and Sete Barreiros are found (figure 1).

The region is in the geomorphological unit called Provincia Serrana, which is characterized by being an extensive corridor of parallel highlands, with approximately $400 \mathrm{~km}$ in length by $40 \mathrm{~km}$ of width, extending to the Pantanal de Cáceres until the city of Paranatinga (Valadão 2012). The area is inserted in the Alto Paraguai Basin and has three water courses and its tributaries: Rio Saloba (West), Pindeiwar Creek (South), Três Ribeirões (North), also includes countless small perennial and temporary water courses classified according to their salinity in fresh water or salty water (Sonoda 1991).

The climate is tropical AW Megathermal, according to köppen's classification, with seasonality 


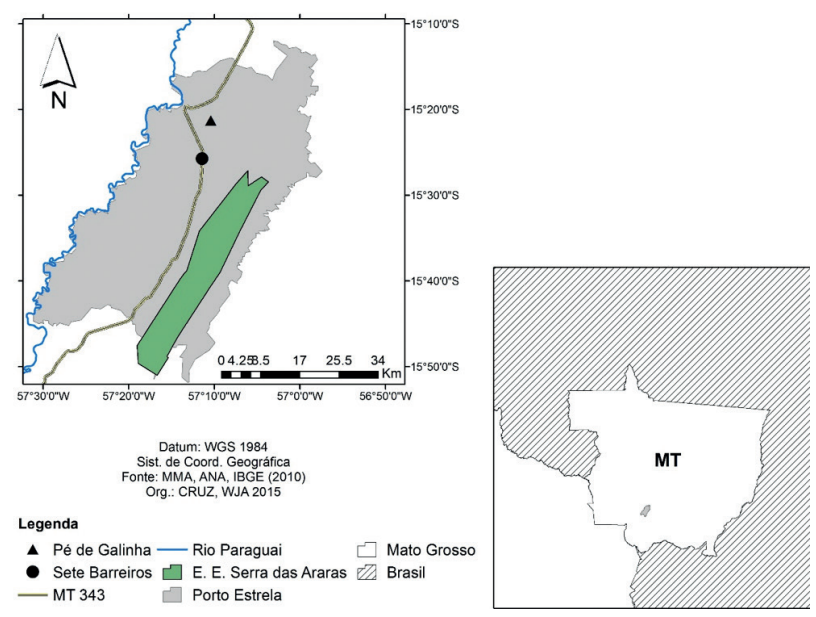

Figure 1. Location of the communities Pé de Galinha and Sete Barreiros, Porto Estrela, Mato Grosso State, Brazil.

comprising the rainy period from October to April and the dry period from May to September (Valadão 2012). The annual rainfall is estimated in $1.400 \mathrm{~mm}$. The minimum and maximum temperatures averages are $20^{\circ} \mathrm{C}$ and $32{ }^{\circ} \mathrm{C}$, respectively (Gonçalves \& Gregorin 2004).

The region is inserted in the Cerrado biomes and Amazon (IBGE 2015). The vegetation is characteristic of Central Brazil, with various types physiognomic, of which the following stand out: Campo limpo, campo cerrado, campo sujo, cerrado sensu stricto, cerradão and with considerable extensions occupied by gallery forests, veredas and swamps that accompany the water courses (Santos-Filho \& Silva 2002).

The Community Sete Barreiros was the first place where some families were established, because at the time of expulsion it was offered for the families that they moved to another place, where the lands were brownfield. Some families, without option in the face of the pressure, agreed to move to the new site, where had to redo their lives. Established in that new place that was located near the MT-343, they built plantations and homes, but after some years ago the land owner appeared and delimited his surrounding area, leaving the families in the Community literally on the verge of the MT-343 road.

At the edge of MT-343, the descendants of the Community Bocaina formed the community known as Sete Barreiros, comprising 15 families, from which 10 participated of this study. The families do not have any document of the land and survive from the plants that they grow in this place, or perform daily tasks for the farms in the region. The families belong to six family trunks, of which the older people died, thus, the community is composed of the children and grandchildren of those who have suffered violence of expulsion. It is worth remembering that, in spite of the majority of the children being removed from the Serra da Bocaina in childhood, some of them were already younger, and these together with their parents who have already passed away, constructed a collective memory on expulsions and mainly on their traditions, allowing continuity, so resistant, of their culture.

The Community Pé de Galinha, located forward of the urban area of the municipality of Porto Estrela, consisting of 17 families, 12 of which participated in the study, was formed from a family trunk that came out of the Serra da Bocaina before the conflicts aggravation. The reason why this family moved, was due to the death of a family member by jagunços at that time, and due to this, the feared family decided to establish where the community is today. The interlocutors of this research are part of four family trunks, the majority has some degree of kinship, and those who do not have it, possess relations of cronyism. The families have no lands document and also as in Sete Barreiros live up to the plants cultivation, and some of them are retired.

After many struggles, the Community has joined and formed the Association Negra Rural Quilombo Bocaina, recognized as quilombo community by Palmares Foundation, by means of Decree No 195 dated from November 29th 2011, published in the Official Gazette No 230 dated from December 01st 2011, and they expect that the law is enforced, and they return to their place.

Data Collection - All those involved in the study were informed about the objective and the methodology of the study and the data collection outside initiated after the acceptance of the same, due to the fact that they have been cheated in several ways over the years by people saying "wanting to help", nowadays the interlocutors with fear of being harmed refuse to sign any paper or document. Overall 22 actors have agreed to participate in this study.

About the methodological procedure we performed semi-strutured, informal interviews, and free list, according to Bernard (1988, Martin 1995), in which the first data were collected on the plants cultivated in the backyard and in the plantations. After the interviews, it was requested to the interlocutor to show the plants that he had in his place, this time, were asked questions about use, origin and plant management, in order to know about trade and the seedlings movement. 
During the visits to the interlocutors it was performed participant observation, "method traditionally used in anthropology, which consists in the seizure, by means of a daily interaction between the researcher and the members of the community studied, the way it operates the crop in question and as social actors see their world. It can provide the scenario in which is used the plants" (Amorozo 1996).

In the data record, we used the field diary where the whole process of field was described that helped in knowledge seizure about culture, as well as, in recordings and photographs, previously authorized by the interlocutors (Leal 2013). For identification of the botanical material, it was used photographic recording of cultivated species. The plants were identified through the use of online databases: List of species of Brazil's flora (2015), the Plant List (2015), Tropics (2015), Neotropical Herbarium Specimens (2015), in addition to query the specialized literature. For the botanical classification System APG IV (2015) was adopted.

Data Analysis - For data analysis, we used the absolute frequency (Af.) and relative frequency (Rf.) of properties with the presence of plant species most cited by interlocutors, where: Af = number of occurrence of the species in the properties $(\mathrm{QTI})$ and $\mathrm{Rf}=\left[\mathrm{n}(\mathrm{qti}) / \sum \mathrm{qt}\right]$ $\times 100$. We also carried out linear regression analyzes, among the variables richeness of species in the food and medical categories, present in the home gardens, according to the age of the interlocutor, and the time of residence in the place. We also applied the Detrended Correspondence Analysis (Hill 1980), an analysis which sorts the sampling units in accordance with the variation of the floristic composition, thus, the closer the sampling units, the larger the degree, with this, we tried to check with this analysis the existence of similarity between the gardens. The species diversity was analyzed and compared between the gardens of two areas (Communities Pé de Galinha and Sete Barreiros) using the diversity profiles obtained by the series of Rényi's (1995). For the calculations of the statistic we used the R program (2009).

\section{Results}

The 22 families do not have a large area for the cultivation of a farm as they did in the past, every family has a different area, so some of them have a larger area than others. The interlocutors perform the plants cultivation in what we call "garden", which can be understood as the physical space around the residence of the family group, in which the family interacts permanently with the cultivated plants and animals raised, there is the development over the generations, because farmers experience and make innovations constantly, allowing them to adjust to their needs (Méndez et al. 2010).

Those parties which do not have space to cultivate the farm in their garden do it in lands loaned by friends, relatives or even a person who donates the space for them to plant, so the terrain is not "dirty". But all of them cultivate "even if it is only to pay the expenditures". Facing that, we charted a universe of 180 species of plants cultivated, used as food and medicinal plants, but which also aggregated other functions such as ornamental and utilitarian. In this last case, they are used to making fences, straw coverage, wood utensils, wood for construction of houses, among others.

The plants recorded are identified and organized according to their use category, form of use and absolute and relative frequencies in table 1 (Appendix). The specimens that had higher occurrence in gardens and farms, on the basis of absolute frequency, were respectively: The specimens that had higher occurrence in gardenss and farms, on the basis of absolute frequency, were respectively: banana (22), papaya and cassava (19 each), sweet sop and mango (18), bocaiuva (17) guava and lemon Galician (16), oranges and sugar cane (15), cashew, chives and chili peppers (14), all belonging to the category of food use. The cultures with the highest number of varieties were: Cassava (24), banana (19), sugarcane (10), papaya (nine), potato and mango (seven).

The cultivated plants are originated from seeds and creoles seedlings, some brought from Serra da Bocaina, other obtained through gain and/or exchange with friends and relatives of the neighboring communities. The interlocutors reported with regret that some varieties of cassava, banana and sugar cane are not adapted to the new environment in which they live, and thus ended up losing the variety, other grew up but not as in the same way as when they were in the place where they lived, once a lady commented: "These papaya trees lasted up to two years with fruit, in Bocaina...".

It was observed the cultivation of several domesticated plants as the vegetables, the "jabuticaba", cashew nuts, etc.; we found in the gardens several fruit species, some of which were collected and planted in the garden, either due to their flavor, to the 
adaptation to the environment, lastly, the fact is that the interlocutors collect plants from the jungle and keep them in their places.

In the gardens, the plants are cultivated in a polyculture form, in their majority composed of fruit trees, utilitarian, ornamental and some from the plantation are also grown in the gardens. It was observed a strategy of interlocutors aiming to optimize the space planting species of different habits such as trees, shrubs, herbs, vines, being this diversity one of the most frequent characteristic in the garden's crops.

The inhabitants have a special care with the garden and with the plants, performing periodic weeding, cleaning, soil fertilization, irrigation. This is the time that they take advantage to check the plant's condition, whether it has any pests, if there is shortage of fertilizers, lastly, in case there is any problem they solve as soon as possible. The fertilizer used is the organic fertilizer, scraps of vegetable parts (leaves, branches, stems), food scraps and cattle and chicken'feces, are items that are present in the family unit (figure 2).

When residents produce vegetables they surround the area, due to the hens, and sometimes pigs, which are raised freely in the garden. The remains of tree trunks were formerly used with greater frequency in planting vegetables, what they call "Acuri palms dung" that it is the Palm tree stipe in decomposition. To eliminate pests, the interlocutors, make use of simple and inexpensive strategies; they use compositions of "angico" leaf with alcohol or water, the leaf from neem tree also in alcohol or in water, this is called a "calda bordaleza", or use the tanned leaf in cattle urine.

In the farm, plants cultivation is performed in polyculture, in which they always plant more than one species, also with different habits. In a plantation, for example, two recorded two varieties of potatoes, "carioca" beans, gherkin, okra and chilies. They perform the crops rotation, in accordance with the plants "ages", for example, in this same plantation, before maize had been planted. The cultivation is performed through the direct drilling, the residents who have a larger area only for the plantation, plow the land ${ }^{5}$ and then plant the seeds with no fertilizer, as they say "only with God's help".

In the planting, some families utilize the moon phases and the day of the week to plant species. For

5 The plowing is performed by means of machinery, in which the community's inhabitants pay the third parties to perform the service.
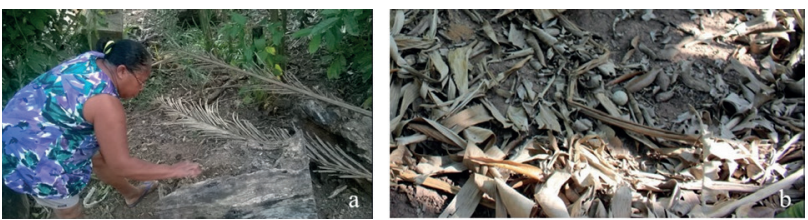

Figure 2. a. resident removing manure from the trunk of a tree in decomposition. b. "specks" left on the soil to be used as a fertilizer. Photo: Thaís Coelho, 2015.

example, Mr. Laércio plants cassava after three days of new moon, and the best days of week to plant are the tuesday, wednesday and thursday. You can also work on Saturday and Sunday, but on Friday and on Monday it is not possible "it is still and the plants do not grow", as he said: "For today anyone has these things". "For us who have that old custom, you know. My people if it were not for planting in these days, they do not really plant". According to Mr Luís, bananas must be planted on the full moon's eve, because a big bunch grows, thick finger; in the waning crescent moon, beans corn, bananas, delay longer to grow but they are born healthy; some of the other interlocutors share the same knowledge and beliefs.

In addition to food plants, medicinal plants obtained a considerable representativeness, thus, in this study we also recorded a wealth of 97 medicinal species. The plants that had the highest number of occurrence were: cotton (14), Barbados cherry and "boldo" (13), pumpkin (11), coffee, Santa Maria herb and squaw mint (10). This richness demonstrates that the tradition of use of medicinal plants continues being used constantly in popular medicine, for the preparation of household remedies.

The medicinal species were indicated as a remedy for different organism diseases. For these plants 51 therapeutic functions were allocated, such as: deworming, cholesterol, throat, influenza, ulcer, anxiety, cough, blood pressure, stomach, burns, gastritis, diabetes, measles, indigestion, rheumatism, etc (table 1). The graph below (figure 3 ) shows the parts of the plants used more in food and medicinal ethnic categories.

This chart shows that for the medicinal category the leaf part was the most cited, confirming what was seen on the field in which they make a lot of leaf tea, and they often make it in a preventive way. The different ways of preparing that are recorded were: tea (47 species); bath (16); cooked (14); in the water (nine); macerate (four); the juice, beaten and milk (three); in "cachaça" and in alcohol (two); in wine, roasted, powder, steamed, in syrup, lead drying, in cooking oil, heated, smashed in water (one). 


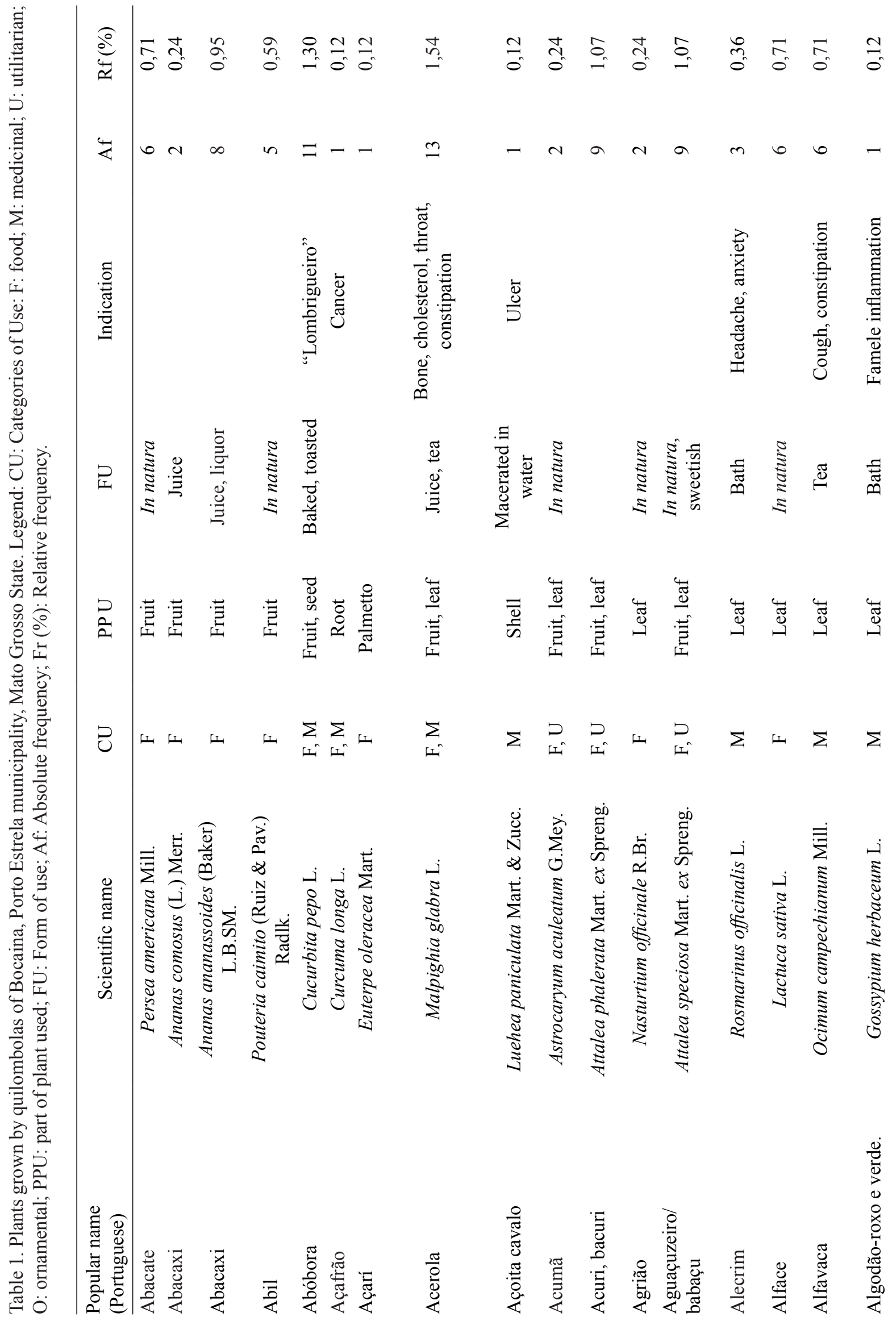




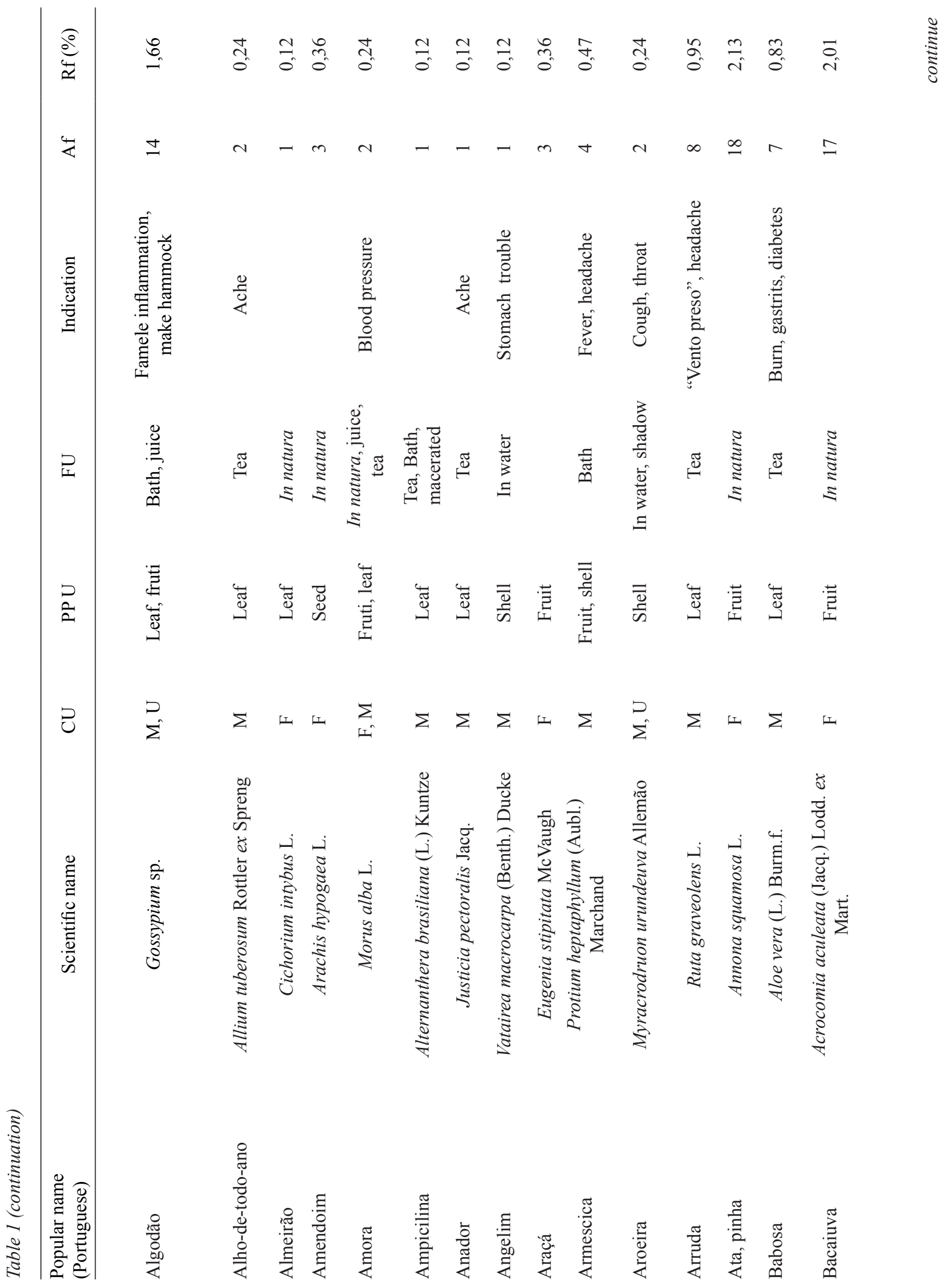




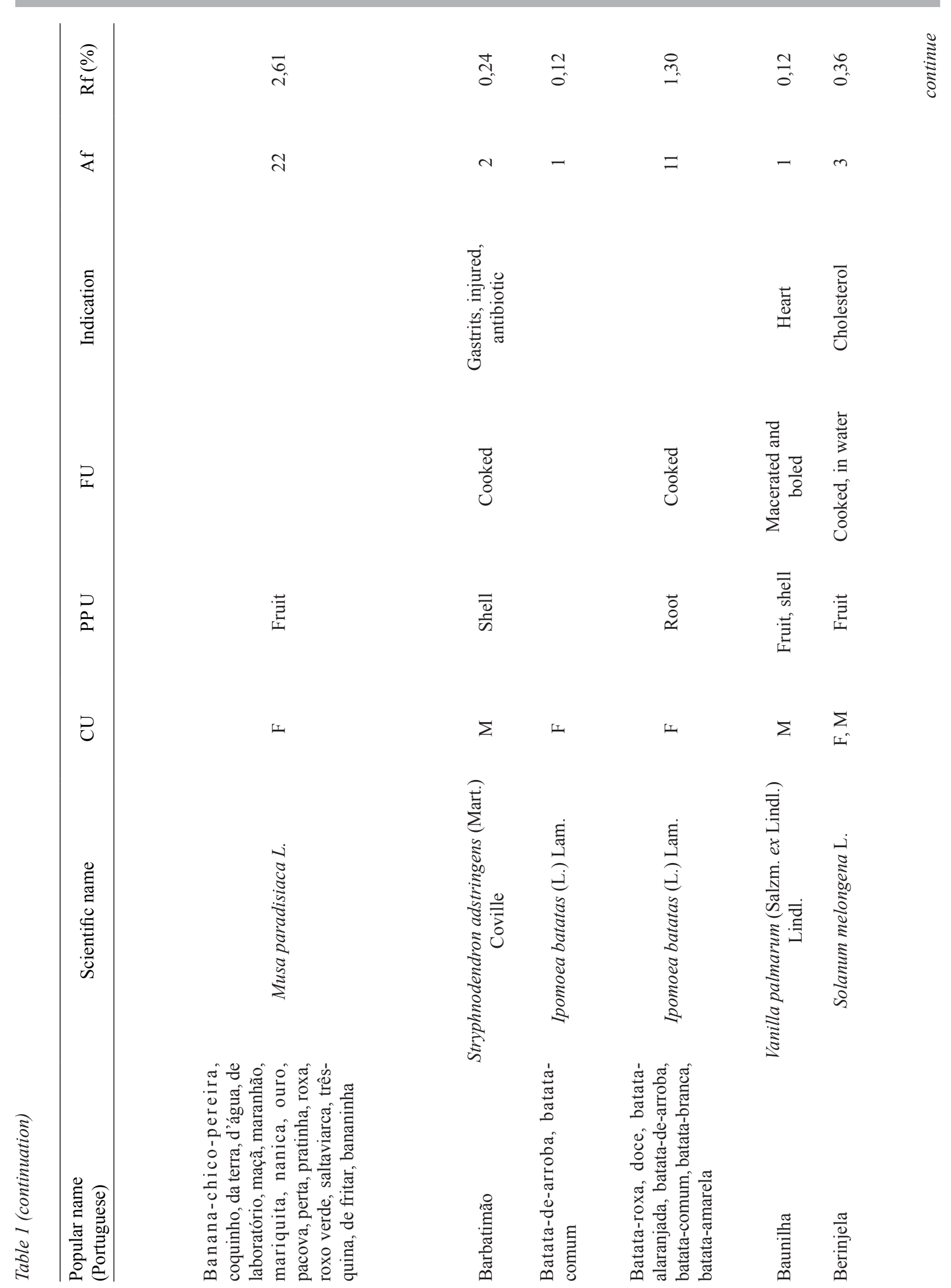




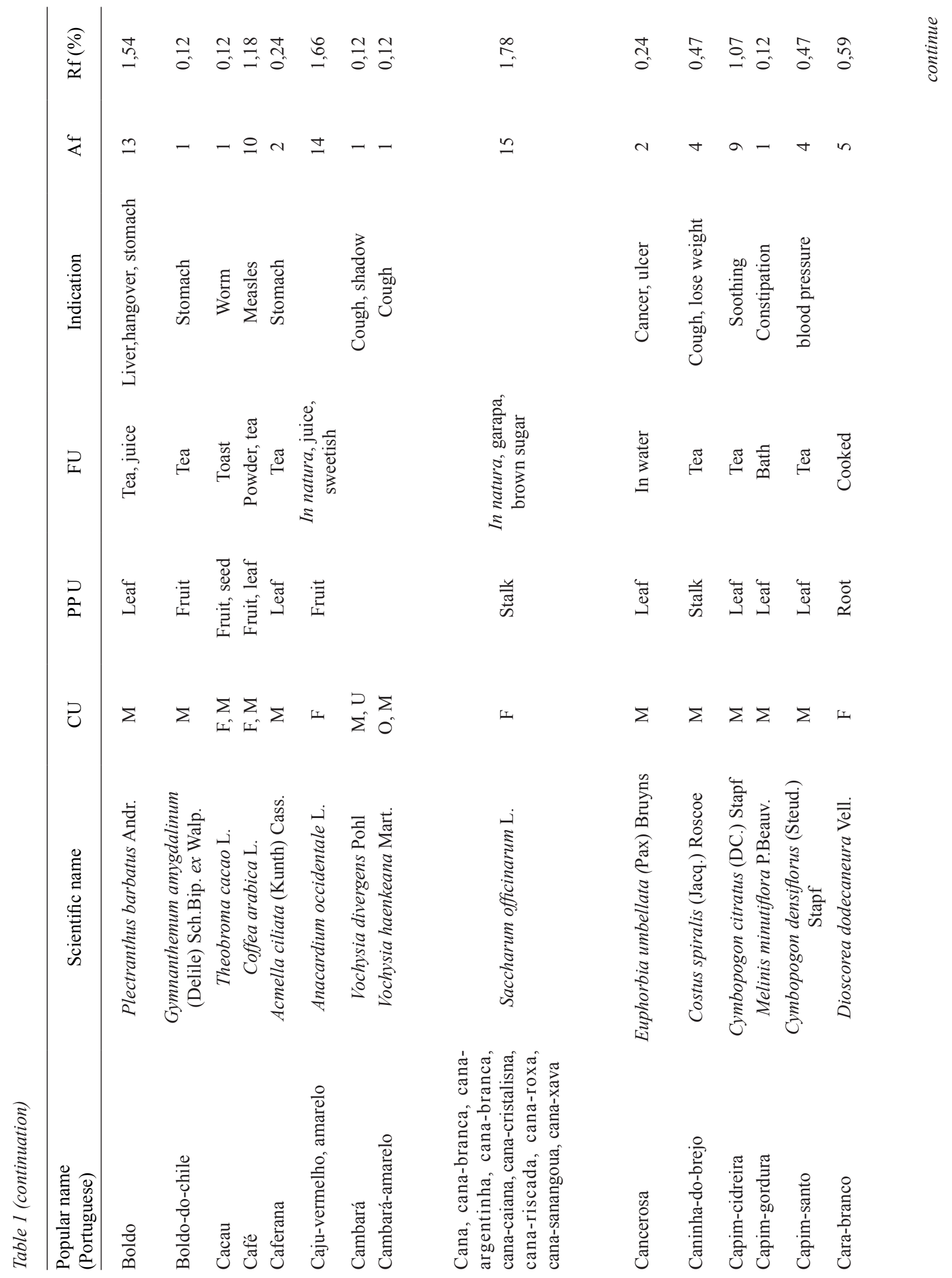




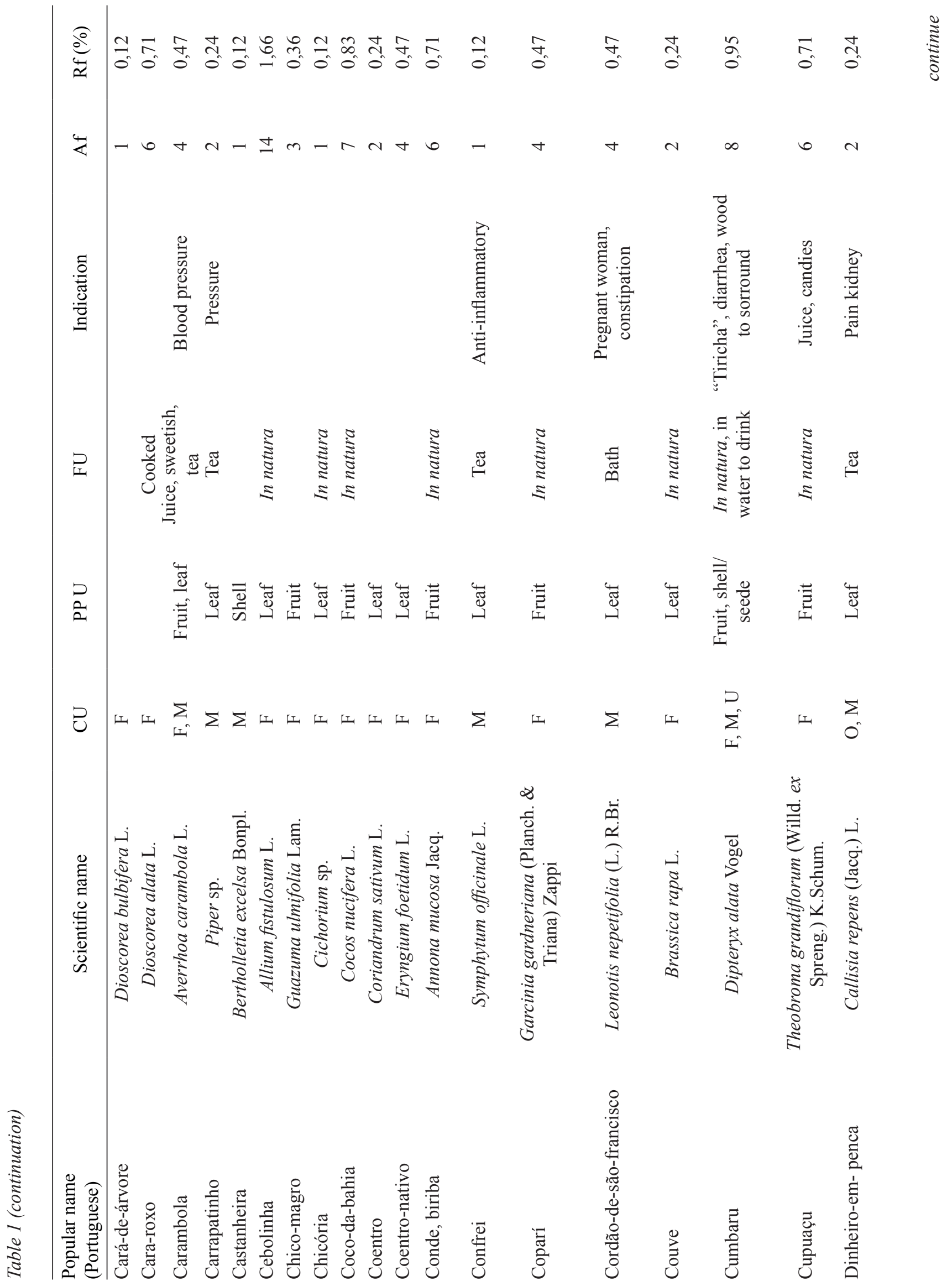




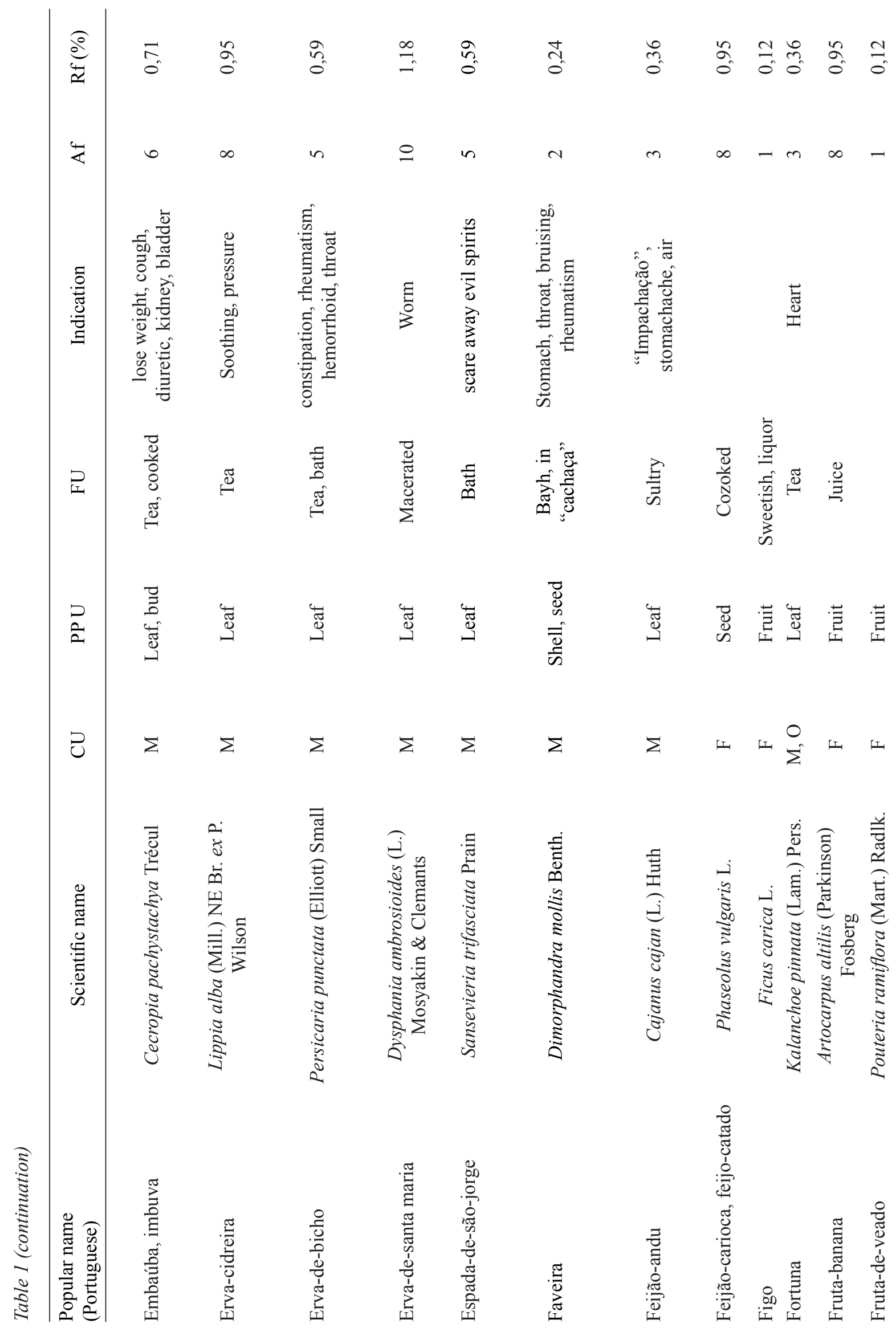




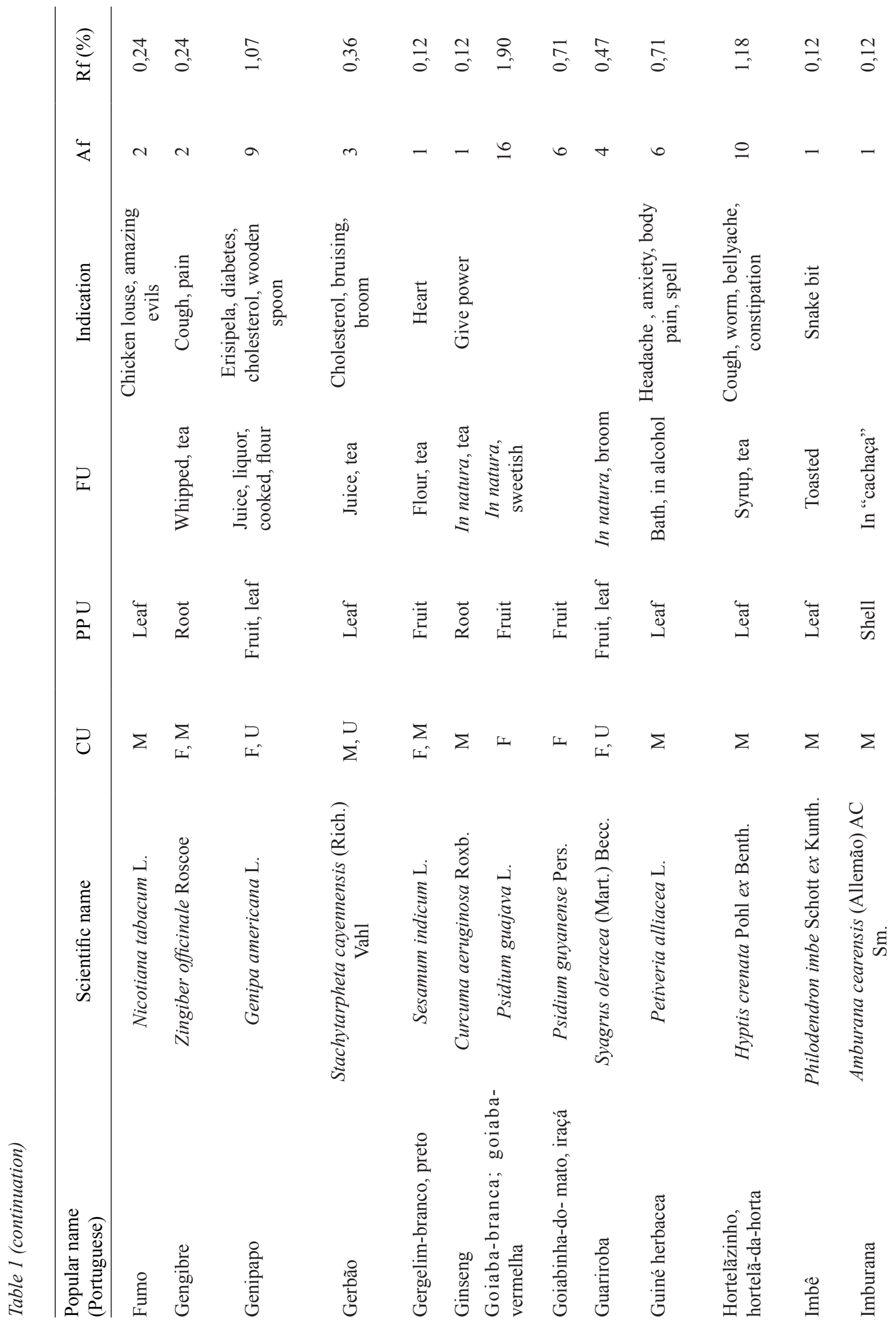




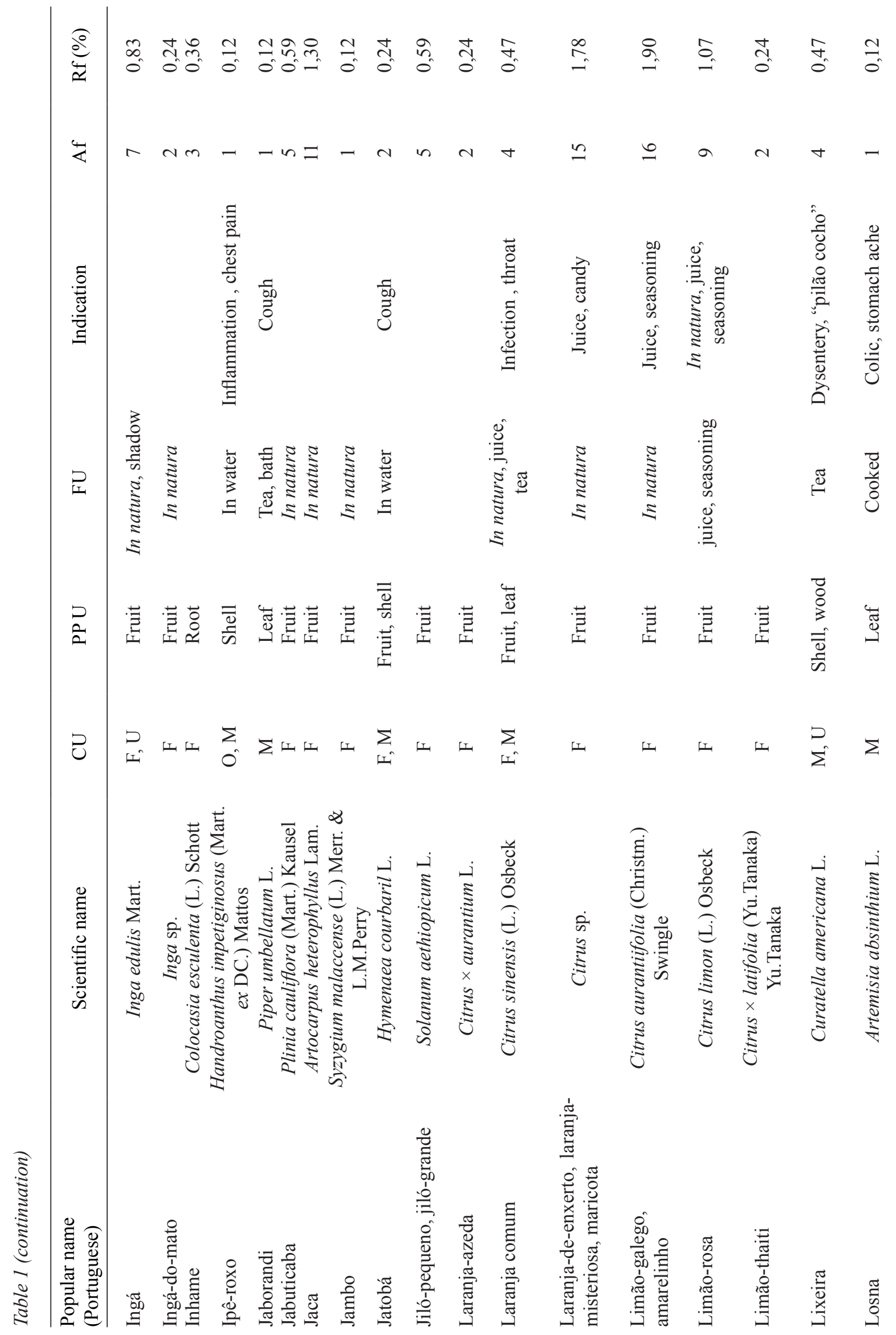


Hoehnea 44(2): 211-235, 2017

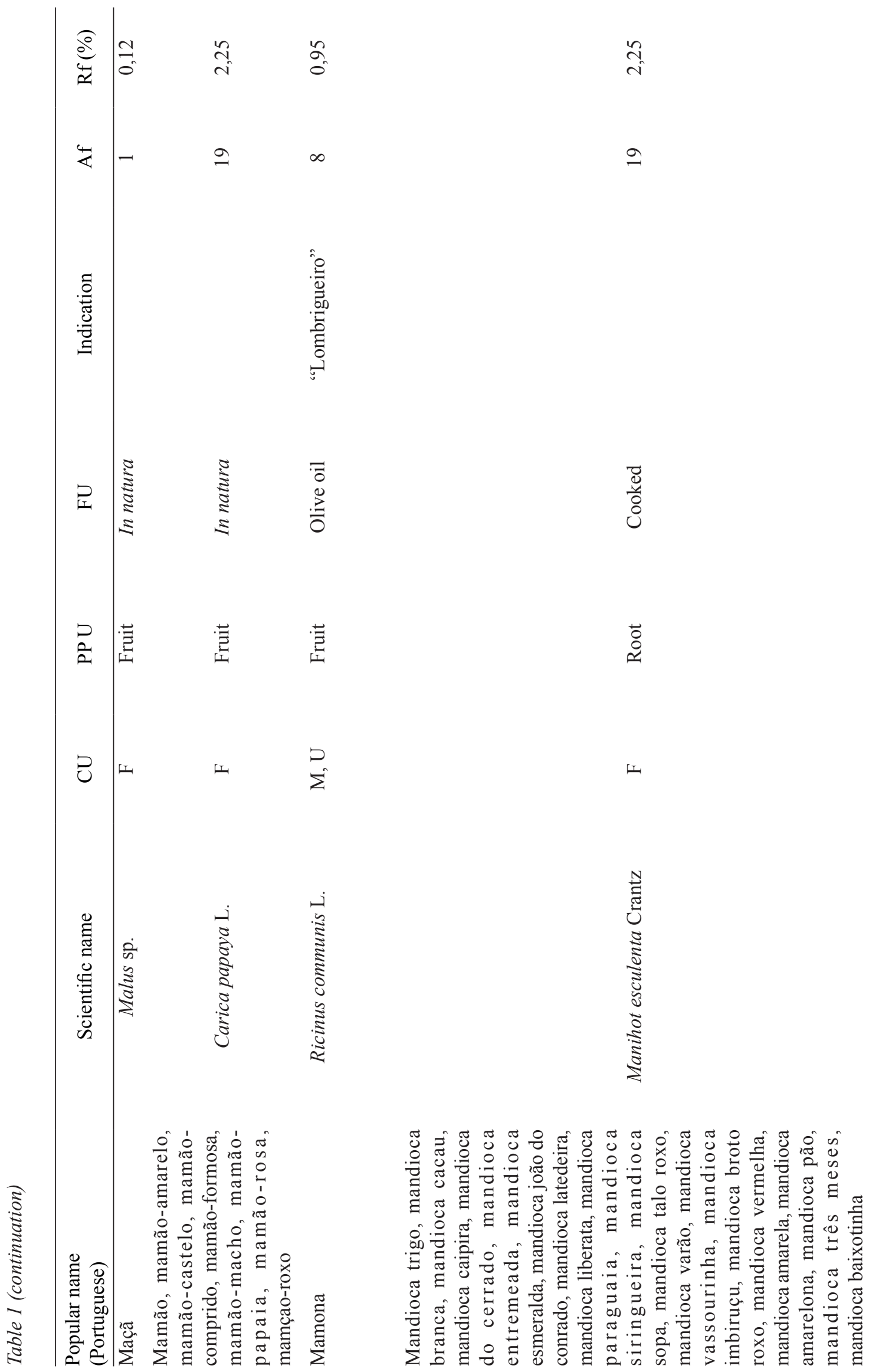




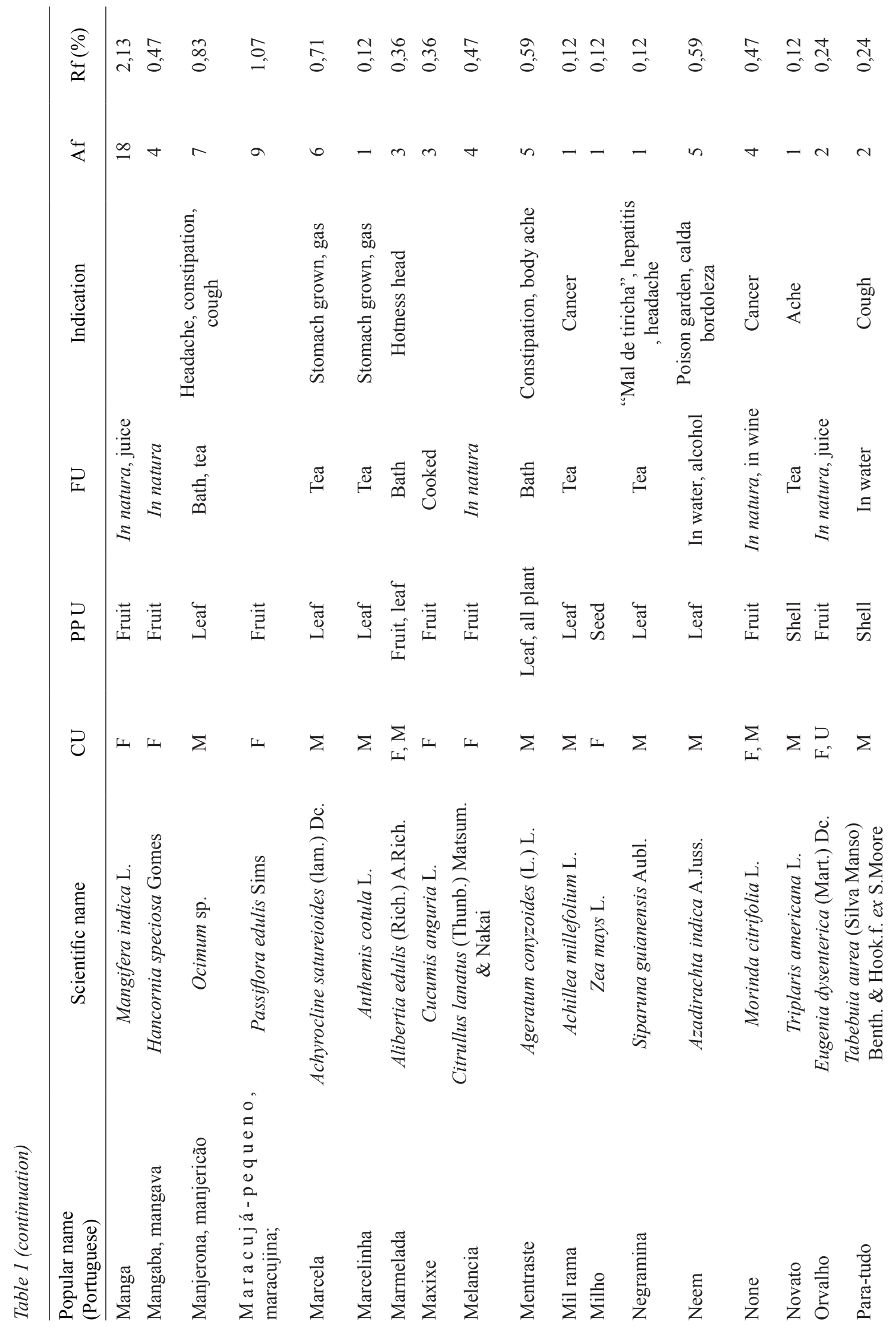




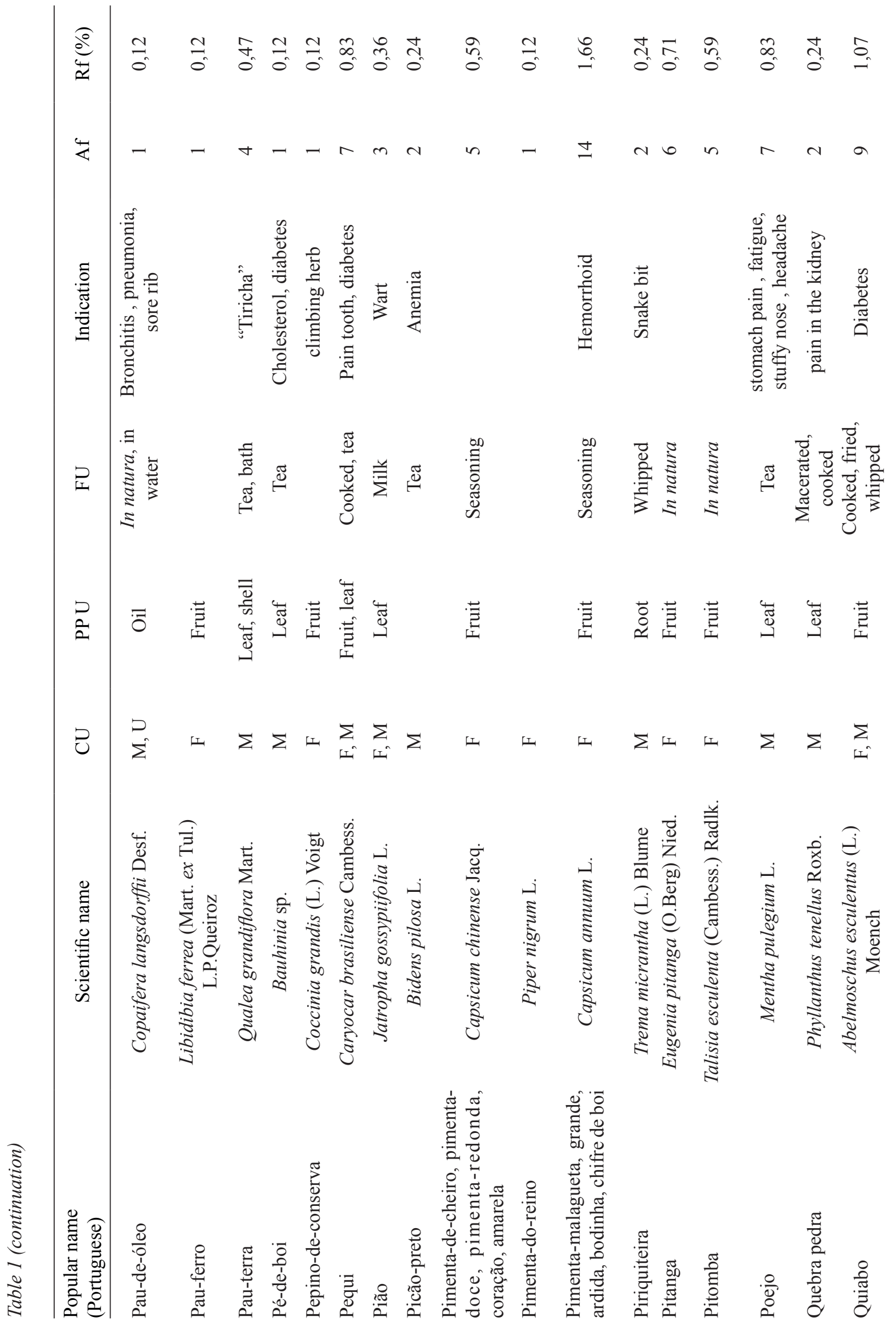




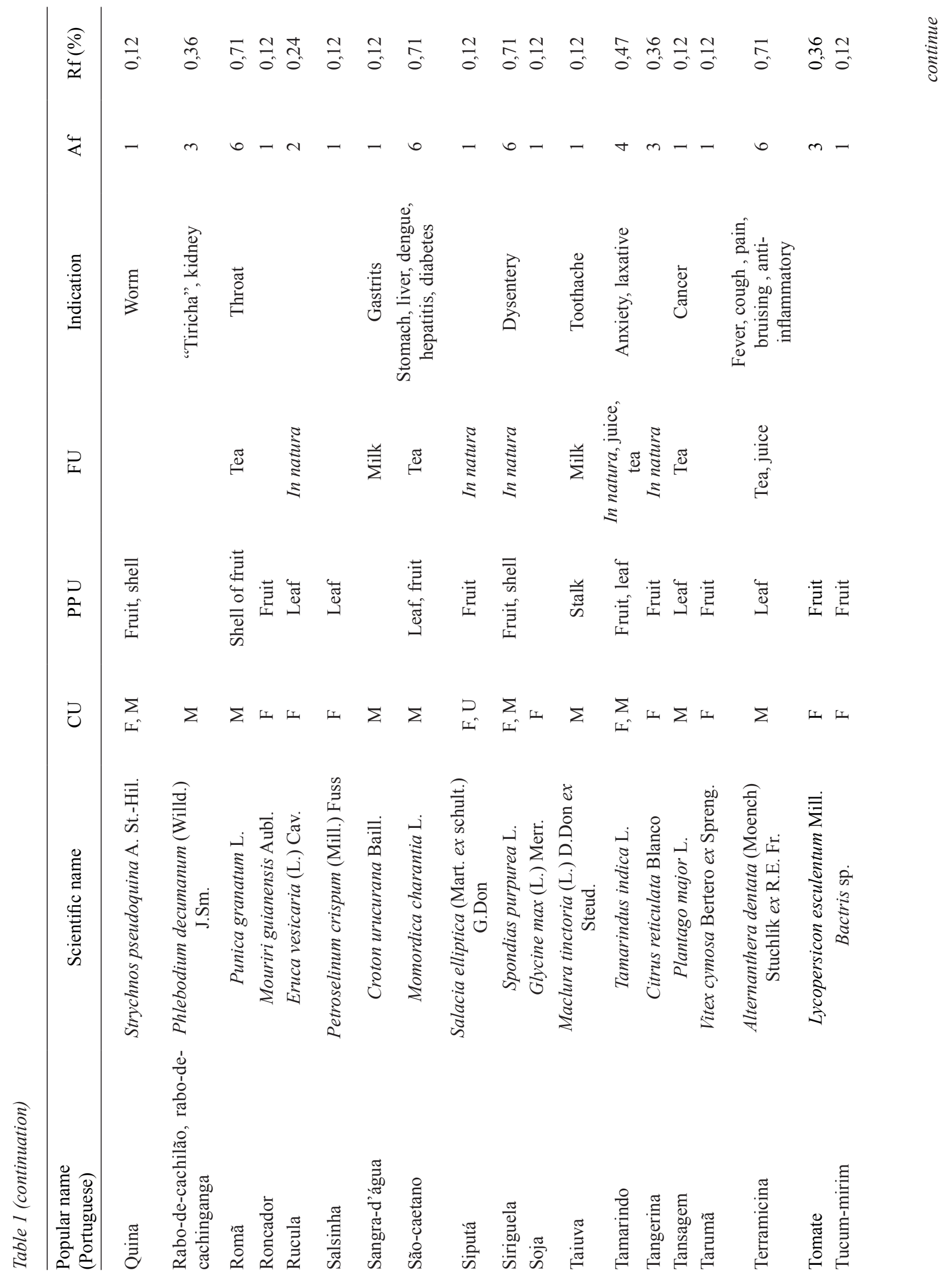




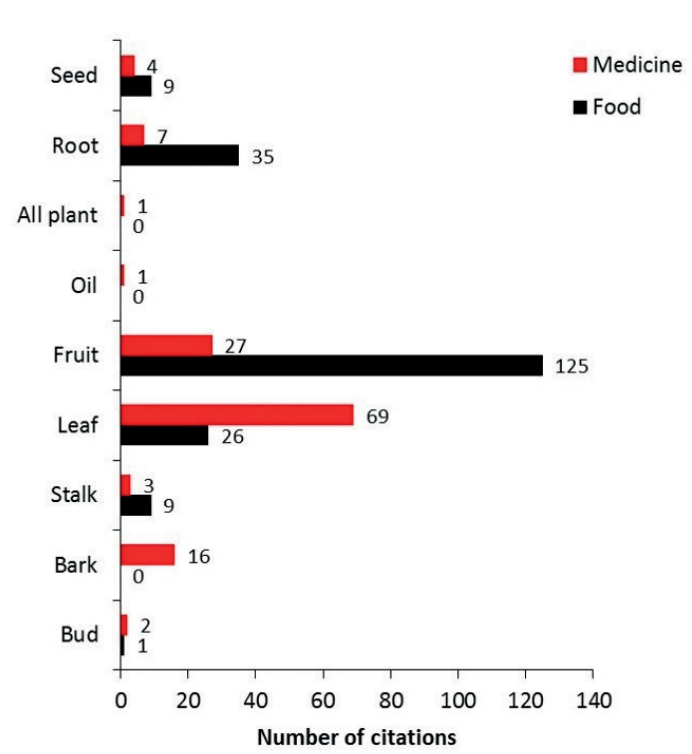

Figure 3. Plant parts used by quilombolas, Bocaina, Porto Estrela, Mato Grosso State, Brazil.

Linear regression analysis was performed to verify if the richness of species, present in the home gardens in the different categories, food and medicine, is related to the age and residence time of the interlocutors (figures 4 and 5). In general, not only age but also the interlocutor's residence time did not influence in the species richness present in the home gardns of the different categories.

In the DCA analysis we see that the similarity between some gardens is very high, proving the usual exchange of seeds, as shown in figure 6 . In the analysis of diversity profile, it was compared plant diversity between the community areas (figure 7).

It is worth pointing out that, the plants dumbcane (Dieffenbachia seguine (Jacq.) Schott), Saint George's sword (Sansevieria trifasciata Prain) and Guinea henweed (Petiveria alliacea L.), are often plants cultivated in front of the residence, whose function is to scare away "evils", and the "cumba" (Craniolaria integrifolia Cham.), where its seed can be used against the "insects attach" (for exemplae, snake bite) and evil eye. Rue had medical indication, but a family commented that we cannot say bad things about it such as it stinks, or else the plant dies.

\section{Discussion}

In both communities, everybody lived in the Serra da Bocaina and therefore they descend from a time when access to the town was very difficult, and it was only done when they really needed, thus, people did 

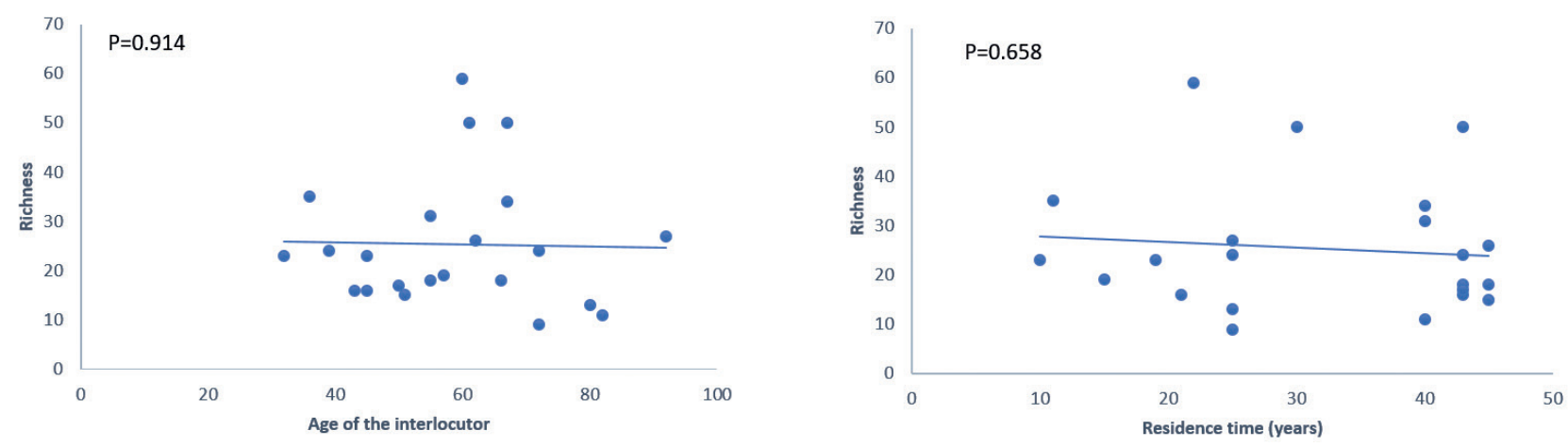

Figure 4. The trend line of species richness in the food category, in function of age and residence time of the interlocutors of the quilombola Community Bocaina, Porto Estrela, Mato Grosso State, Brazil.
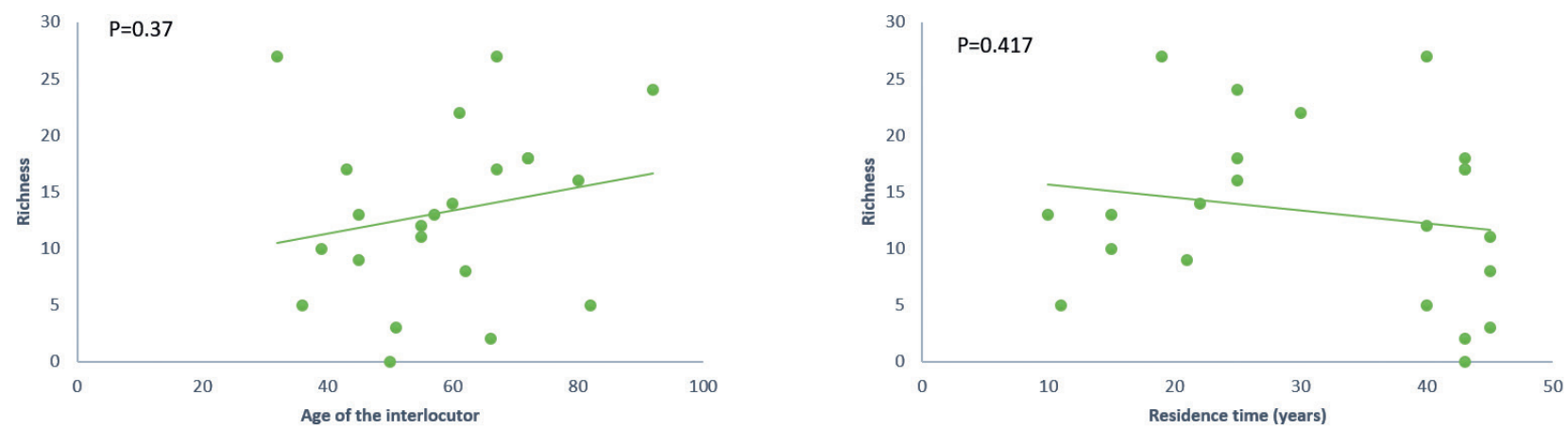

Figure 5. The trend line of species richness in the medicinal category, in function of age and residence time of the interlocutors of the quilombola Community Bocaina, Porto Estrela, Mato Grosso State, Brazil.

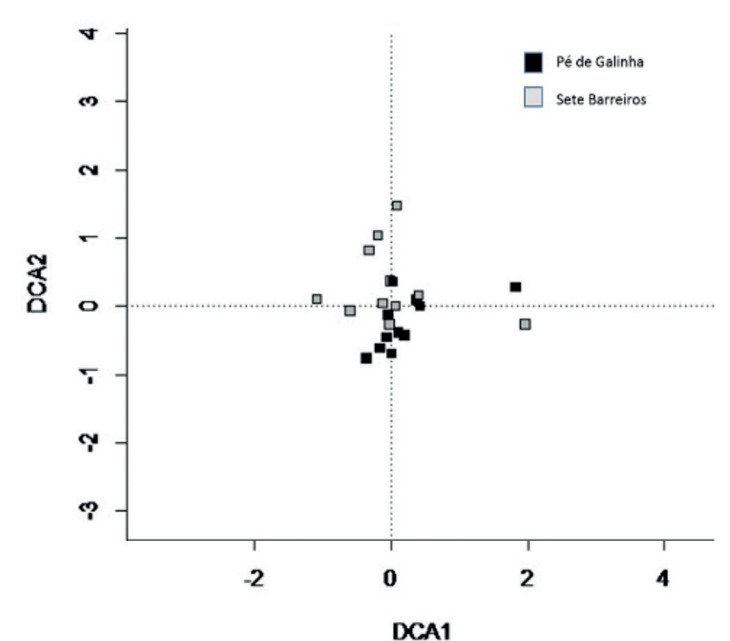

Figure 6. Sorting produced by the detrended correspondence analysis on the basis of abundance of the species in 22 gardens of the Quilombo Community Bocaina's inhabitants. Porto Estrela, Mato Grosso State, Brazil. not study and their teaching was done at the farm. This forced the majority, having no school training, learned to deal with plantations since childhood and cultivate various medicinal, ornamental plants and for other utilities. In this way, to cultivate and take care of the plants, in traditional agricultural communities is learned since early stages in life, as the children accompany adults in plantations and take part in the daily tasks, and those who get used to planting will hardly ever stop practicing such activity (Amorozo 2002a).

The reduction of the space for planting, one of the consequences of deterritorialization, is what shocks the interlocutors the most, it is how Mr. Emílio told us: "Other times I used to deal with small plantation up there in two acres of borrowed land, then I never coped with the plantation anymore, I am even willing to do it again, life was better for me'. For Camacho (2011) 


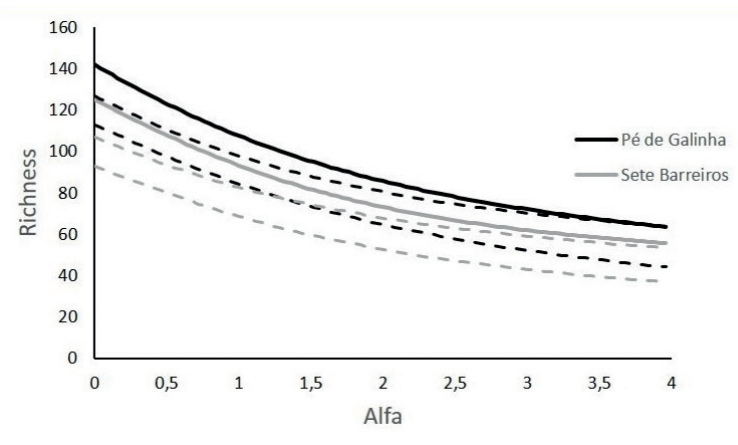

Figure 7. Shows that although the species richness is greater in the area of Pé de Galinha, if compared with Sete Barreiros, diversity does not differ between areas.

the limitation of access to land and the useful species, is a factor that drives the small farmer to overexploit the scant resources available in order to survive, and therefore make use of conservation strategies which try to retain the stock of natural resources which it proves for him environmental goods and services. With this, the garden is an important factor to maintain self sufficiency in food, despite the variability in the degree of production (Albuquerque et al. 2005).

The production for own consumption is interpreted as a strategy that family groups use aiming at ensuring the autonomy on a vital dimension: feeding, so families can choose food according to their tastes and traditions and habits and they bear the necessary know-how-to-do to cultivate them (Grisa et al. 2010, Oakley 2004). The growing of varieties allow the interlocutors always have at their disposal a foodstuff resource, thus the interlocutor plants three or four varieties of cassava and with this he has the root the whole year (Galluzzi et al. 2010).

The interlocutors reported with regret that some varieties of cassava, banana and sugar cane are not adapted to the new environment in which they live, and thus ended up losing the variety, other grew up but not as in the same way as when they were in the place where they lived, once a lady commented: "These papaya trees lasted up to two years with fruit, in Bocaina...". In this sense, Bardsley (2003) says that agricultural systems and genetic materials which maintain high levels of tolerance to changes in social and environmental conditions are particularly valuable for the biodiversity conservation. In addition, despite of the ecological and economic adversities, the community is still doing the cultivation of these plants, which leads us to Darnhofer et al. (2016), who underline that the resiliency in family farming is influenced by the way in which the farmer uses the resources at their disposal, what options and potential he perceives, based on their values, their experiences and networks in which they are involved.

The banana plantations, cassava, papaya, sugar cane and potatoes are intrinsically linked to the culture of the community, for since the time in which they lived in the Serra da Bocaina, they planted these plants, which are part of the typical food menu of the community, such as cassava soup with meat or with chicken, flour, beiju, banana soup, fried banana, roasted and boiled, dried fish with cassava, papaya dessert, panela, sugar cane juice. In this respect, the consumption is not a simple food ingestion, but also a form of pleasure and cultural expression, which means that the agricultural practices and "culture" are interlaced, thus, in the absence of one the other disappears (Peterson 2000, Padmanabhan 2011). In this sense, aspects related to symbolic representations, as well as culinary and aesthetic preferences, have an important role in the maintenance of agricultural diversity (Amorozo 2008).

The plants have been with the community for many years, they have replanted over the years so that the seedlings and seeds are not lost, since many species have already been lost with the deterritorialization. In this respect, Mrs. Luíza reinforces: "I have been planting year to year, not losing the seed, banana and papaya, pineapple, satsuma, I have been replanting, and this is old, from my father, grandfather, and wherever we go we take along the seed and the plant". This fact reveals the continued use of creoles varieties, in this respect Jackson et al. (2007) and Altieri (1992) say that small farmers, in particular in developing countries, continue growing various traditional variety (local and commercial), contributing to the productivity, sustainability and resiliency of human livelihoods.

Many of the food plants are domesticated plants such as the vegetables, "jabuticaba" etc; we found in the gardens several fruit species, some of which were collected and planted in the garden, either due to their flavor, to the adaptation to the environment, lastly, the fact is that the interlocutors collect plants from the jungle and keep them in their places, an attitude with plays an important role on the biodiversity maintainance. The polyculture system of planting and crop rotation are extremely important, because of the diversity of cultures combinations, and the way these are used to maintain or increase production, reduce risk and assist in conservation, as well as promotes 
the recycling of nutrients (Altieri 1992, Brookfiel $\&$ Stocking 1999). The coverage of the soil used by the community does not harm the environment, on the contrary, it occurs the addition of organic matter, and at no cost, and it provides some benefits to the agroecosystem, such as: to protect and conserve the soil surface, minimize the erosion, to protect from oxidation or other chemical deterioration, preserving the soil and water, thus, the coverage becomes crucial to maintain the productive process (Altieri 2000). In this way, the sustainable agriculture is based on recognition of the natural processes and its constitution on the resources available locally (Hamilton et al. 2003, Altieri 1989).

The species diversity, the accumulation of organic matter, the recycling of biomass and nutrients, minimizing losses of resources through soil cover and water, and the maintenance of high levels of functional biodiversity, are traditional methods of cultivation which seem to be underlying the sustainability, giving to these systems the ecological balance (Brookfield \& Stocking 1999, Altieri 2004, Albuquerque et al. 2005, Hole et al. 2005). The moon phase is an important factor planting time, thus, the interlocutors use the moon phases to guide the planting of certain crops, causing these become more flattering and tasty. In this sense, the direct and attentive observation of the environment allows the quilombola communities establish relations between the natural events, such as phases of the moon, rainfall, climate, etc., correlating with events of agronomic, biological and productive type (Toledo \& Barrera-Brassols 2008, Pilla \& Amorozo 2009). Thus, the importance of astronomical rhythms in agriculture and in daily activities are old, and although this knowledge is being lost, still remains in practice of small farmers, in agriculture, forestry and animal management (Jovchelevich 2014).

The plants are used in accordance with the necessity of the person, and in different ways, with this, people will manage their production with focus on its uses, such as food, drink, medicine, etc., with the intention of preventing health problems, or subsequent treatments (Alarcón et al. 2015). In this study, in addition to food plants, medicinal plants obtained a high representation, revealing an important role in the life of the interlocutors. The medicinal plants species are managed and used for therapeutic or preventive purposes, knowledge of the species, the management and tillage, preparation techniques of medicines, the knowing about which is the best part of the plant used, the best harvest technique, as well as the form of preparation, constitute the element called "traditional knowledge associated with biodiversity" (Stellai et al. 2006). This knowledge is present in the community under study and has been transmitted from generation to generation, and kept in their gardens.

The use of the leaf for medicinal purposes, is due to the fact that this is the structure that is found in the plant in most of its life time, as well as the easy access, and the presence of major metabolites. What is very common in studies of medicinal plants in Brazil, as demonstrates the work by Oliveira (2013), Löbler et al. (2014), David \& Pasa (2015).

The most common form of use was the tea, as they use the leaf to a great extent, it is expected that the most frequent preparation form be this one. This result agrees with other studies such as the Amorozo (2002b) which found a universe of 228 species, the most common mode of administration were the teas with 124 species and the baths with 83 species.

Still on medicinal plants it was observed the plants adoption introduced for the relief of diseases "considered new in society", demonstrating the introduction and incorporation of new knowledge acquired with the modern society. Revealing what Shackeroff and Campbell (2007) say that culture is a human invention, under constant review and reinvention with the people inside the community and society trying to adjust it to meet the need of its human dimension. In addition, Oliveira (2012) says that the plants understood in their enormous diversity, lend themselves to build memories and knowledge according to their sensitive properties, so, the knowledge is, thus materialized in the landscape, but not for this reason they are fixed and immutable.

In the food category the fruit was the one which had the largest number of citations, reflecting the reality of the community, because this has many species of trees that are most often used in food; it is as Mrs. Rita told us: "My father gave me this garden, we plant only in this garden, the things that we have we plant in this garden, then you see we have so many fruits, then we do not need to buy them in the local market.".

The linear regression analysis expressed in figures 4 and 5 shows that the richness of cultivated grown in the home gardens of the different interlocutors has no relation to the age and residence time of the interlocutors, demonstrating that factors such as old age in the field and rural exodus from young people, are present in the community, since the amount of plant specimens planted in the home gardens varies 
according to the physical and social conditions of the intervieweds. The "old age in the field", in which the inhabitants, subjects with advanced age, health debilitated, no longer able to produce as much as in their youth, thus, many species are no longer cultivated over time, this may be observed in the following report: "I have planted very much, now I can't, because my knee and my leg, have problems. When I was younger here was full of plants, now I can no longer do things, this is setback". In addition, the leaving of the sons from the field is another factor that contributes for that to happen, so today the children have access to education in the city, and usually when they finish high school they try to professionalize, making it possible for them to search for a "better" life to settle down in the city.

Amorozo (2013) says that the difficulties experienced in the field and the apparent advantages of urban, modern life, are an attraction for the younger generations, and one of the reasons why the agricultural labor is not being completely restored, as the active population is aging. This situation was also observed in the study of Marchetti et al. (2013) in which they assert that a factor that have caused the decrease of agricultural activity, is the aging of the field population and the lack of replacement of family labor, and with this, it prevents the assimilation of traditional knowledge, leading to the loss of agricultural diversity.

The usual exchange of seeds and seedlings is in the community culture, because several times in the field the interlocutors commented that they had managed to obtain the seedlings with the neighbor or with a relative. Or then as when I saw Mrs. Joaquina taking seed of passion fruit for Mrs. Luzia; Mrs. Luzia distributing lettuce seedlings for Mrs. Rita, Mrs. Giselda and Mr. Laercio. Mrs. Rita's report reflects this issue: "Comadre Luzia exchanges, she asks if I have some seedlings to exchange, I have one that she does not have, so we just go and exchange". Amorozo (2002b) considers that an important practice among the small farmers, which is the movement of propagating material between relatives and neighbors, guaranteeing the security against the loss of planting material for the next season, in addition to maintain the germplasm.

For Valle (2002), the traditional agriculture cultivates varieties that historically have contributed to the improvement of plants, because they are sources of genes for resistance to pests and diseases and environmental stresses, constituting an important depositary and maintainer of varieties accumulated over generations. Altieri \& Merrick (1987) comments that the maintenance of traditional agriecosystems is the only sensible strategy to preserve in repositories in situ cultures germplasm. Wood \& Lenné (1997) assures that the in situ conservation is dynamic, with cultures adapted to the changes of environmental conditions, allowing farmers to manage the variations of the species according to their need, besides allowing the samples to be continuously available, as needed.

The analysis of diversity profile, showed that there is no significant difference in the diversity of species between the areas of the Community. This shows that despite of the distance between the areas, the interlocutors by means of seed exchanges and seedlings maintains a similar diversity, i.e. both areas using the same plants. Thus, one may infer in case there was no such exchange of germplasm, the Pé de Galinha area could contain the greatest diversity, as that is where the greatest species richness. In addition, Begossi (1996) states that the diversity index can help us to see Homogeneity and heterogeneity aspects of plants within the population. Thus, according to the author, a low diversity of plants may mean some loss of local knowledge, assuming that the original diversity was high and can show a greater diversity of use of the plant. In this sense, it was observed several utilities for a same plant specimen, corroborating with Begossi (1996).

The use of plants for "scaring away evil eye" and "as amulets" are common in traditional communities, Verde et al. (1997) says they belief that evil eye is common in all cultures since antiquity, and around this has been created a whole universe of prayers and rituals to prevent the presence and dissemination, many of these rites are accompanied by certain plants. In the study of gardens by Carniello (2007) in BrazilBolivia frontier 13 species of plants considered for protection were registered, or how the author puts mystical.

However, the quilombola Community Bocaina still cultivates the plants traditionally, and hold knowledges and practices on biological diversity. Such knowledge was obtained by means of constant observations in the environment, by selecting the information more or less relevant, in order to keep the knowledge of the most important nature, and thus being transmitted from generation to generation orally or experimentally. Peterson (2000) says that people know, through long experience, that the conservation of a diversity of beliefs and practices will help them in different ways and often 
in difficult conditions in the long term. In addition, the most important when it comes to traditional ecological knowledge, it is the ability to generate, transform, transmit and apply the knowledge Gómez-Baggethum \& Reyes-García 2013).

\section{Acknowledgements}

To interlocutors who participated of this study, and to everybody of the community. To the "Mestrado em Ciências Ambientais of the University of the State of Mato Grosso for enabling the realization of this work and for the infrastructure available. Coordination for the Improvement of Higher Education Personnel (CAPES), by granting the scholarship.

\section{Literature cited}

Alarcón, R., Pardo-de-Santayana, M., Priestley, C. \& Morales, R. 2015. Medicinal and local food plants in the south of Alava (Basque Country, Spain). Journal of ethnopharmacology 176: 207-224.

Albuquerque, U.P., Andrade, L.H. C. \& Caballero, J. 2005. Estrutura e florística de quintais no Nordeste do Brasil. Journal of ambientes áridos 62: 491506.

Altieri, M.A. \& Merrick, L.C. 1987. In situ conservation of crop genetic resources through maintenance of traditional farming systems. Economic Botany 41: 86-96.

Altieri, M.A. 1989. Agroecology: a new research and development paradigm for world agriculture. Agricuture, Ecosystems \& Environment 27: 37-46.

Altieri, M.A. 1992. Agroecological foundations of alternative agriculture in California. Agric. Agricuture, Ecosystems \& Environment 39: 23-53.

Altieri, M.A. \& Nicholls, C.I. 2000. Teoría y práctica para una agricultura sustentable. Serie Textos Básicos para la Formación Ambiental. PNUMA 235. Red de Formación Ambiental para América Latina y el Caribe. México.

Altieri, M.A. 2002. Agroecology: the science of natural resource management for poor farmers in marginal environments. Agricuture, Ecosystems \& Environment 93: 1-24.

Altieri, M.A. 2004. Linking ecologists and traditional farmers in the search for sustainable agriculture. Frontiers in Ecology and the Environment 2: 35-42.

Amorozo, M.C.M. 1996. Abordagem etnobotânica na pesquisa de plantas medicinais. Plantas medicinais: arte e ciência - um guia de estudo interdisciplinar. UNESP, São Paulo, pp. 47-68.

Amorozo, M.C.M. 2002a. Agricultura Tradicional, Espaços de Resistência e o Prazer de Plantar. In: U.P. Albuquerque, A. G. C. Alves, A. C. B. L. Silva, V. D. Silva (orgs.). Atualidades em Etnobiologia e Etnoecologia. Sociedade Brasileira de Etnobiologia e Etnoecologia, Recife, pp. 123-131.
Amorozo, M.C.M. 2002b. Uso e diversidade de plantas medicinais em Santo Antônio do Leverger, MT, Brasil. Acta Botanica Brasilica 16: 189-203.

Amorozo, M.C.M. 2008. Maintenance and management of agrobiodiversity in small-scale Agriculture. Functional Ecosystems and Communities 2: 11-20.

Amorozo, M.C.M. 2013. Sistemas agrícolas de pequena escala e a manutenção da agrobiodiversidade - uma revisão e contribuições. FCA - UNESP, Rio Claro.

Barthel, S., Crumley, C.L. \& Svedin, U. 2013. Biocultural refugia: combating the erosion of diversity in landscapes of food production. Ecology and Society 18: 71-86. Available in http://dx.doi.org/10.5751/ES-06207180471 (acesso em 19-II-2016).

Bardsley, D. 2003. Risk alleviation via in situ agrobiodiversity conservation: drawing from experiences in Switzerland, Turkey and Nepal. Agriculture, Ecosystems \& Environment 99: 149-157.

Begossi, A. 1996. Use of ecological methods in ethnobotany: diversity indices. Economic botany 50: 280-289.

Benton, T.G., Vickery, J.A. \& Wilson, J.D. 2003. Farmland biodiversity: is habitat heterogeneity the key? Trends in Ecology \& Evolution 18: 182-188.

Bernard, H.R. 1988. Research methods in cultural anthropology. Sage, New-bury Park, Calif. pp. 149-179.

Boef, W.S. 2007. Biodiversidade e Agrobiodiversidade. In: W.S. Boef (org.). Biodiversidade e Agricultores: Fortalecendo o manejo comunitário. L\&PM, Porto Alegre, pp. 36-40.

Brookfield, H. \& Stocking, M. 1999. Agrodiversity: definition, description and design. Global environmental change 9: 77-80.

Carniello, M.A. 2007. Estudo etnobotânico nas comunidades de Porto Limão, Porto Alambrado e Campo Alegre, na fronteira Brasil-Bolívia, Mato Grosso Brasil. Tese de Doutorado, Universidade Estadual Paulista, São Paulo.

Darnhofer, I., Lamine, C., Strauss, A. \& Navarrete, M. 2016. The resilience of family farms: Towards a relational approach. Journal of Rural Studies 44: 111-122.

David, M. \& Pasa, M.C. 2015. As plantas medicinais e a etnobotânica em Várzea Grande, MT, Brasil. Interações 16: 97-108.

Diegues, A.C. 2000. Etnoconservação da natureza: enfoques alternativos. Etnoconservação - novos rumos para conservação da natureza. Núcleo de Apoio à Pesquisa sobre Populações Humanas e Áreas Úmidas Brasileiras, São Paulo.

Emperaire, L. 2004. La biodiversité agricole en Amazonie brésilienne: ressource et patrimoine. Journal d'agriculture traditionnelle et de botanique appliquée, 42 anné. Un terrien des îles. A propos de Jacques Barrau. pp. 113-126. 
Galluzzi, G., Eyzaguirre, P. \& Negri, V. 2010. Home gardens: neglected hotspots of agro-biodiversity and cultural diversity. Biodiversity and Conservation, 19: 3635-3654.

Gómez-Baggethun, E. \& Reyes-García, V. 2013. Reinterpreting change in traditional ecological knowledge. Human ecology: an interdisciplinary jornal 41: 643-647.

Gonçalves, E. \& Gregorin, R. 2004. Quirópteros da Estação Ecológica da Serra das Araras, Mato Grosso, Brasil, com o primeiro registro de Artibeus gnomus e A. anderseni para o cerrado. Lundian 5: 143-149.

Grisa, C., Gazolla, M. \& Schneider, S. 2010. A produção "invisível" na agricultura familiar. Autoconsumo, segurança alimentar e políticas públicas de desenvolvimento rural. Agroalimentaria 169: 65-79.

Hamilton, A.C., Pei Shengji, J.K., Ashiq A.K., LagosWitte, S. \& Shinwari, Z.K. 2003. The purposes and teaching of Applied Ethnobotany. People and Plants working paper 11. WWF, Godalming, UK.

Hill, M.O. \& Gauch, H.G. 1980. Detrended Correspondence Analysis, an improved ordination technique. Vegetatio 42: 47-58.

Hole, D.G., Perkins, A.J., Wilson, J.D., Alexander, I.H., Grice, P.V. \& Evans, A.D. 2005. Does organic farming benefit biodiversity? Biological conservation 122: 113-130.

Hunn, E.S. 1999. The value of subsistence for the future of the world. Ethnoecology. In: V. D. Nazarea (ed.). University of Arizona Press, Arizona, pp. 23-36.

IBGE. 2016. Instituto Brasileiro de Geografia e Estatística. Cidades@. Available in http://www.cidades.ibge.gov.br/ painel/painel.php?lang $=\&$ codmun $=510685 \&$ search $=\%$ 7Cporto-estrela (access in 20-III-2016).

Jackson, L.E., Pascual, U. \& Hodgkin, T. 2007. Utilizing and conserving agrobiodiversity in agricultural landscapes. Agricuture, Ecosystems \& Environment 121:196-210.

Jovchelevich, P. 2014. Influence of moon rhythms on yield of carrot (Daucus carota L.), under biodynamic management. Building Organic Bridges 1: 77-80.

Leal, O.F. 2013. Paisagem etnográfica: Imagens, inscrições e memória nos cadernos de campo. Iluminuras 14: 62-84.

Lista das Espécies da Flora do Brasil. 2015. Lista de Espécies da Flora do Brasil. Jardim Botânico do Rio de Janeiro. Available in http://floradobrasil.jbrj.gov.br/ (access in 20-VIII-2016).

Löbler, L., Santos, D., Santos Rodrigues, E. \& Santos, N.R.Z. 2014. Levantamento etnobotânico de plantas medicinais no bairro Três de Outubro, da cidade de São Gabriel, RS, Brasil. Revista Brasileira de Biociências 12: 81-89.

Machado, A.T. 2007. Biodiversidade e Agroecologia. In: W.S. Boef (org.). Biodiversidade e Agricultores: Fortalecendo o manejo comunitário. L\&PM, Porto Alegre, pp. 40-45.
Marchetti, F.F., Junior Massaro, L.R., Amorozo, M.C.M. \& Butturi-Gomes, D. 2013. Maintenance of Manioc Diversity by Traditional Farmers in the State of Mato Grosso, Brazil: A 20-Year Comparison. Economic botany 67: 313-323.

Martin, G.J. 1995. Ethnobotany: a methods manual. Routledge.

Méndez, R.M., Ávila, M.C.A., Reys, L. M. A., CahuichCampos, D., Jácome, A.G., Dávilla, M.A.V. \& Wal, H. 2010. Avances en el estudio de los huertos familiares del sur de méxico. In: A.M Fuentes, M. T.P. Silva, R.M. Méndez, R.V. Azúa, P.M. Correa, T.V.G. Santillán (eds.). Sistemas Biocognitivos Tradicionales: Paradigmas en la Conservación Biológica y el Fortalecimiento Cultural. México, pp. 108-116.

Nodari, R.O. \& Guerra, M.P. 2015. A agroecologia: estratégias de pesquisa e valores. Estudos avançados 29: 183-207.

Neotropical Herbarium Specimens. 2015. Available in http://www.fieldmuseum.org (access in 21-III-2016).

Oakley, E. 2004. Home gardens: a cultural responsibility. Leisa-Leusden 20: 22-23.

Oliveira, J.C.D. 2012. Entre plantas e palavras. Modos de constituição de saberes entre os Wajãpi (AP). Dissertação de Mestrado, Universidade de São Paulo, São Paulo.

Oliveira, W.A. 2013. Os recursos vegetais e o saber local nos quintais da Comunidade de Santo Antônio do Caramujo, Cáceres, Mato Grosso, Brasil. Dissertação de Mestrado, Universidade Federal de Mato Grosso, Mato Grosso.

Pacari, A. 2006. Uso Popular de Plantas Medicinais do Cerrado. In: Ministério do Meio Ambiente. Brasília. Agrobiodiversidade e diversidade cultural. MMA/SBF.

Padmanabhan, M. 2011. Women and men as conservers, users and managers of agrobiodiversity: A feminist social-ecological approach. The Journal of SocioEconomics 40:968-976.

Pilla, M. \& Amorozo, M. 2009. O conhecimento sobre os recursos vegetais alimentares em bairros rurais no Vale do Paraíba, SP, Brasil. Acta Botanica Brasílica 23: 1190-1201.

Peterson, A. 2000. Alternatives, traditions, and diversity in agriculture. Agriculture and human values 17: 95-106.

R Development Core Team. 2009. R: language and environment for statistical computing. R Foundation for Statistical computing, Vienna, Austria. Available in http://www.R-project.org (access in 10-X-2015).

Santos-Filho, M. \& Silva, M. N.F. 2002. Uso de habitats por mamíferos em área de Cerrado do Brasil Central: um estudo com armadilhas fotográficas. Revista Brasileira de Zoociências 4:57-73.

Shackeroff, J.M. \& Campbell, L.M. 2007. Traditional ecological knowledge in conservation research: problems and prospects for their constructive engagement. Conservation and Society 5: 343-360. 
Shiva, V. 2003. Monoculturas da mente. Gaia, São Paulo.

Sonoda, F.A. 1991. Resgate das relações entre as comunidades circunvizinhas à Estação Ecológica da Serra das Araras-MT, como estratégia de uma proposta de Educação Ambiental. Monografia de Especialização em Educação Ambiental. UFMT. Mato Grosso.

Stellai, A., Kageyama, P.Y. \& Nodari, R. 2006. Politicas públicas para agrobiodiversidade. In: MMA. Brasília. Agrobiodiversidade e diversidade cultural. MMA/SBF. pp. 59-68.

The Plant List. 2013. Version 1.1. Published on the Internet. Available in http://www.theplantlist.org/ (access in 21-III-2016).

Toledo, V.M. \& Barrera-Bassols, N. 2008. La memoria biocultural: la importancia ecológica de las sabidurías tradicionales. v. 3. Icaria Editorial.

Tóthmérész, B. 1995. Comparison of different methods for diversity ordering. Journal of vegetation Science, 6: 283-290.
Tropicos.org. 2015. Missouri Botanical Garden. Available in http://www.tropicos.org (access in 21-III-2016).

Valadão, R.M. 2012. Birds of the Estação Ecológica Serra das Araras, Mato Grosso, Brazil. Biota Neotropica. v. 12, 3: 263-281.

Valle, T.L. 2002. Coleta de germoplasma de plantas cultivadas. In: M.C.M. Amorozo, L.C. Ming, \& S.P. Silva (eds.). Métodos de coleta e análise de dados em etnobiologia, etnoecologia e disciplinas correlatas. UNESP/SBEE/CNPq. Rio Claro, pp. 129-154.

Verde, A., Núñez, D.R., \& Castro, C.O. 1997. Plantas mágicas de la provincia de Albacete: maléficas, protectoras y mágico-curativas. Al-Basit: Revista de estudios albacetenses 40: 143-156.

Wood, D. \& Lenne, J.M. 1997. The conservation of agrobiodiversity on-farm: questioning the emerging paradigm. Biodiversity \& Conservation 6: 109-129. 